Pakistan Journal of Nutrition 14 (3): 141-145, 2015

ISSN 1680-5194

(C) Asian Network for Scientific Information, 2015

\title{
Prospect of Dairy Goat Production for Small-Scale Enterprise in Payakumbuh West Sumatra
}

\author{
Yulianti Fitri Kurnia, Ferawati, Reswati and Khalil \\ Faculty of Animal Husbandry, Andalas University, Campus II Payakumbuh, West Sumatra, Indonesia
}

\begin{abstract}
Twenty-five goat farms were surveyed to gain data and information about population, farming practices, goat performances and market prospect. Data were then analyzed to compare the prospective of dairy goat farm in compare to meat-types as a livestock enterprise suitable for small-scale or part time farmers. Three dairy goat farms were then selected to define milk production, quality and marketing. Samples of fresh milk were taken from each farm and analyzed for microbial pathogens and physical characteristics. Results found from the 25-selected farms, there were 14 farms (56\%) raising meat-type goat and 11 dairy goat farms (44\%), but the total population of dairy goat of about 395 animals was much higher than that of meat type goat of 200 animals. Each dairy goat farm kept about 35.9 animals, while meat-type goats were only 14.3 animals. Dairy goat farm has better prospect in compare to meat-types as an alternative livestock enterprise suitable for small-scale farmer or part-time livestock producer in Payakumbuh region. The mean values of total plate counts and Coliforms were found in the range of 8.04-8.46 and 0.72-4.25 log $\mathrm{CFU} / \mathrm{ml}$, respectively, while Staphylococcus aureus and Escherichia coli were not detected. The physical characteristics of fresh goat milk from Payakumbuh met the national standard. The potential market for goat milk and higher price of bucks made the farmer to be able to increase their farm scale and to raise their goats more intensively in order to achieve optimum production performances and incomes.
\end{abstract}

Key words: Dairy goat production, milk quality, small-scale livestock enterprise

\section{INTRODUCTION}

Region of Payakumbuh which cover Payakumbuh city and 50 Kota district is known as national livestock production center in West Sumatra. Livestock production is mainly dominated by commercial-scale poultry enterprises, especially layer and broiler chickens. Payakumbuh supplies egg and broiler chicken not only in West Sumatra region but also to the neighbor provinces of Riau and Jambi.

Payakumbuh has also potency in goat production. Total number of goat in Payakumbuh was noted about 32,512 heads, where 5,294 heads located in Payakumbuh city and 27,218 heads 50 Kota district (Dinas Peternakan Provinsi Sumatera Barat, 2012). They are run by small-scale farming and distributed mainly in six sub districts, which are dominated by annually smallscale crop estates e.g. Lareh Sago Halaban, Harau, Mungka, Luhak, Payakumbuh Timur and Payakumbuh Barat.

There were no data found about population of dairy goat and goat milk production in this region. Dairy goat production is a promising enterprise for increasing consumption of animal protein as well as raising income level of small-scale livestock producer. This is due to their small body size whereby the initial and maintenance costs are low. Dairy goats contribute to income generation through the sales of milk, milk products, live animals and manure (Macha and Mbaga, 2009). Dairy goats are an alternative source of milk to most rural people who cannot afford to keep dairy cattle. Goat milk is usually sold and can be drunk fresh, although pasteurization is recommended to reduce naturally occurring $S$. aureus and $E$. coli.

Goat milk is a extremely nutritious food, suspension of proteins, carbohydrates and fat that contains numerous vitamins and minerals. Due to its complex biochemical composition and high water activity, goat milk is easily contaminated by bacteria. Contamination in milk is begun at the milking process until consumption. Contaminant bacteria in the milk can be divided into two groups, namely pathogenic and spoilage bacteria. Pathogenic bacteria include $S$. aureus, E. coli and Salmonella sp. and spoilage bacteria are Micrococcus Pseudomonas and Bacillus sp. Due to lack of good farming practices, there is a potency for human health risk by consumption of fresh milk produced by the smallscale farms. According to Suguna et al. (2012), that fresh milk samples from dairy farms in Malaysia were contaminated by foodborne pathogens. The present research was undertaken to explore the prospect of dairy goat in compare to meat-types as an alternative livestock enterprise suitable for small-scale farmer or part-time livestock producer in Payakumbuh region. 


\section{MATERIALS AND METHODS}

Rapid rural appraisal: The study was initiated by discussing with the local government of Payakumbuh city and 50 Kota district that are responsible to livestock services to gain data and information about: general livestock development program, program and budged allocation for goat production and special guidance and services program for goat farmers. A rapid rural appraisal was then undertaken by visiting 25 goat farms and interviewing the farmers as respondent. Farms were distributed in seven sub-district areas located in Payakumbuh city and 50 Kota district. Selection of subdistricts was based goat population, number of farms and agro-ecosystem condition. Farms were selected based on farm scale and accessibility. Farmers were interviewed to gather data and information about farming management practices, goat performances and marketing strategies. Their farms were observed for assessing stall and animal conditions, farmer activities and feeding and feed offered.

Milk sampling and analyzing: Three dairy goat farms were then selected to gain detail information on farming practices, milk production and quality. Farms were selected based on farm scale, management practices and accessibility. Farmers who had an experience of at least three years were interviewed to gain information on farming practices, goat performances, milking procedures and milk handling, marketing. Farms were then observed for evaluation of recently conditions and hygiene status. Milk samples in fresh form were then collected in three different times of weekly interval from each farm. Milk samples were taken in the farms of about $600 \mathrm{ml}$ from milk canes. The milk samples were filled in sterile plastic bags and kept in a cooling box prior to analyzing for microbial and physical qualities.

Microbial analysis were focused on selected bacterial pathogens of total plate count (TPC), Coliforms, presumptive $S$. aureus and $E$. coli, while for physical characteristics the samples were analyzed for fat content, specific gravity, $\mathrm{pH}$ and catalase number. Enumeration of TPC was carried out by employing of standard methods (ISO, 2003b) using plate count agar (PCA, Oxoid CM0325), plates incubated at $37^{\circ} \mathrm{C}$ for $48 \mathrm{~h}$ by spread plate method. Coliforms was carried out by employing of standard methods (ISO, 2003c) using crystal violet neutral red bile lactose (VRBL) agar (Oxoid CM0107), S. aureus was carried out by employing of standard methods (ISO, 2003a) using baird-parker agar (Oxoid CM0275) and E. coli was carried out by employing of standard methods (FDA, 2001). Enumeration of Coliforms was performed by employing three-tube most probable number (MPN) technique. Positive tubes from MPN were streaked onto eosin methylene blue (EMB) agar (Merck) and incubated at $37^{\circ} \mathrm{C}$ for $24 \mathrm{~h}$. The typical colony found was confirmed based on their IMViC pattern. The IMViC test was performed on colonies that showed shiny-metallic green to identify $E$. coli. This procedure are based on standard methods (ISO, 2003c). While, Baird-Parker agar (BPA, Merck) was used to enumerate $S$. aureus in the samples. Characteristic black colonies surrounded by a clear zone were selected and subjected to coagulase and thermonuclease tests for confirmation of S. aureus (BAM, 2004). Fat content were measured according methods described by Dwitania and Swacita (2013) and physical characteristics of specific density, $\mathrm{pH}$ by using lactodensimeter and $\mathrm{pH}$ meter, respectively.

Statistical analysis: Data on goat farm survey were statistically analyzed by using descriptive statistics to compare the prospective of dairy and meat-type goats. The data on bacterial counts of milk samples were converted into logarithm of number of colony forming units per $\mathrm{ml}(\log \mathrm{CFU} / \mathrm{ml})$. Data on milk quality was statistically analyzed for variance analysis in random block design by IBM SPSS version 19. The differences in means were compared using Duncan New Multiple Range Test (DMRT), statements of statistical significance were based on $\mathrm{p}<0.05$ (Steel et al., 1997).

\section{RESULTS AND DISCUSSION}

Importance of dairy goat in compare to meat-type goat: Table 1 showed that total number of goats raised by 25 farms as respondents was 595 heads. There were 14 farms (56\%) raising meat-type goat and 11 farms (44\%) raising dairy goats, but the population number of dairy goats of 395 heads was found much higher than that of meat-type goat of 200 heads. Each dairy goat farm kept about 35.9 goats, while meat-type goat farm was only 14.3 goats. Goat breeds were dominated by Peranakan Etawa (PE) and Jawarandu for dairy types, while for meat types were Kacang and Benggala. Dairy goat farms were mostly developed in the sub-districts of Payakumbuh Barat of Payakumbuh city and Tanjung Haro Selatan which were located in adjacent to the Payakumbuh city.

All dairy goat herds were fed by cut and carry systems. They were offered supplemented concentrated feeds and kept in better housing system, while most of meattype goat farmer $(64.3 \%)$ let their goat to graze during the day and kept in stall at night. Because of better management, performances of dairy goat were also found slightly better than that of meat-type goat. Young does of dairy goat gave birth at the first time at 10.8 month of age with average liter size of 2.1 kids, while meat-type goat of 12.4 month and 2.0 kids, respectively. Sexual maturity and litter size is affected by rearing system. It has been shown to be younger and higher in intensive system than in semi-intensive system (Faruque et al., 2010).

In compare to meat type, raising dairy goat has two advantages for farmers. They earned daily income from selling milk and buck of dairy breed which had higher 
Pak. J. Nutr., 14 (3): 141-145, 2015

Table 1: Survey results from 25 goat farms in Payakumbuh, West Sumatra

\begin{tabular}{lll}
\hline Parameters & Meat-type goat & Dairy goat \\
\hline Number of goat farms, farms & $14(56.0 \%)$ & $11(44.0 \%)$ \\
Education level of farmer, minimum senior high school (\%) & $5(35.7 \%)$ & $8(72.7 \%)$ \\
Total goat population, heads & 200.0 & 395.0 \\
Average number of goat per farm, heads & 14.3 & 35.9 \\
Breed of goat, breeds & 2 (Kacang, Benggala) & $2(\mathrm{PE}$, Jawarandu) \\
Number of farms as major income sources for the farmers' family, farms & $4(28.6 \%)$ & $5(45.5 \%)$ \\
Feeding system with cut and carry, farms & $5(35.7 \%)$ & $11(100 \%)$ \\
\hline Reproductive performances & & 10.8 \\
Average age at first kidding, months & 12.4 & 2.1 \\
Average litter size per birth, kids & 2.0 & $2,000-4,500$ \\
Price of buck, 000 IDR/buck & $1,000-1,500$ & \\
\hline
\end{tabular}

market value than that of local breed. Due to higher body weight and carcass meat portion than local meat-type breed, the selling price of dairy bucks was much higher than that of meat-type breed. The price of dairy bucks ranged from 2,000,000 IDR to 4,500,000 IDR while the price for the local meat type was only $1,000,000$ IDR to $1,500,000$ IDR per head. It was predicted that there will be a prospective market demand in the future for goat meat in West Sumatra in accordance with development of restaurant which offered goat meat curry (or gulai kambing). Goat meat curry is a traditional Minang's cuisine made from meat goat which is cooked by using specific herb spices and might give special sensational taste and flavor to the consumers.

Milk production, quality and marketing: Table 2 shows data on flock sizes, milk production and milk quality of selected three dairy goat farms in Payakumbuh. The number of female goats kept was higher than that of males in all farms. The main reason for high number of females as reported by farm owners was their use for production of milk as a primary output. Other reasons for limited number of male goats were due to limited stall capacity, to avoid inbreeding and to minimize feed cost. This concurs with the finding of Ogola et al. (2010) who reported that all farmers keep dairy goats mainly for milk production.

Based on fat content and physical characteristics, fresh milk goat from Payakumbuh met the national standard. Fat content of about 5.33 to $6.67 \%$ and specific gravity of about 1.0291 to $1.0328 \mathrm{~g} / \mathrm{ml}$ were found relatively high, $\mathrm{pH}$ value of goat milk of 6.5 to 6.6 , the catalase number of about 1.0 to $2.30 \mathrm{ml}$. pH value of goat milk was found in the normal ranges (Sudarwanto and Sudarnika, 2008). Normal $\mathrm{pH}$ value for fresh milk ranged from 6.6 to 6.8 (Sanjeev et al., 2012). Number of catalase is affected by temperature and time associated with the growth rate of bacteria in milk. Bacteria that produce catalase enzyme including $S$. aureus, Coliform, etc. There were several types of bacteria in the goat milk. Saragih et al. (2013) reported there were positive correlation between bacteria count and catalase number. Higher count of bacteria in milk will be follow by higher number of catalase. National standard values for fat content, specific gravity, $\mathrm{pH}$ and the number of catalase number were $\mathrm{min} 3.0 \%, 1.0270 \mathrm{~g} / \mathrm{ml}, 6.3-6.8$ and maks. $3 \mathrm{ml}$, respectively (BSN, 2011; Firmansyah et al., 2004). It means that in terms of fat content and physical characteristics, fresh dairy goat produced by small-scale farms in Payakumbuh met the standard quality.

In term of microbiological quality, pathogenic bacteria of $E$. coli and $S$. aureus were not detected in milk samples collected from the 3 farms, but the values of TPC and Coliforms count were higher than that values of the national standard of $6 \log \mathrm{CFU} / \mathrm{ml}$ and $1.3 \mathrm{log} \mathrm{CFU} / \mathrm{ml}$, respectively (BSN, 2011; BSN, 2009). The highest TPC and Coliforms was found in samples collected from Farm 3 of 8.46 and $4.25 \mathrm{log}$ CFU/ml, respectively (Table 2 ), even though there were no statistically significant differences $(p>0.05)$. Eventhough the number of TPC and Coliform in goat milk at three farms in Payakumbuh exceeded the nasional standar, goat milk from Payakumbuh is still fit for consumption. In general, dairy goat farms in Payakumbuh have not yet implemented good farming practices properly, especially during milking process. The udders before milking were uncleaned and milker's hands unwashed with soap or disinfectant prior to milking. Milk cans and other instruments used for milking were also uncleaned properly. Milking was done directly in the stalls. The farms had no special milking room. There were fast no hygienic treatments for milking goats before milking. These conditions lead to milk easily contaminated by feces or other materials. Alexopoulos et al. (2011) reported that milker's who do not wash their hands with soap or disinfectant and not use mask and gloves during milking, might caused goat milk contaminated. Goat milk can easily contaminated and spoiled due to poor hygienic conditions maintained at farms or improper handling, inadequate storage and transport conditions (Suguna et al., 2012). According to Suwito and Andriani (2012) udder and nipples can be source of pathogenic bacteria if goat were kept in dirty stalls.

Goat milk was sold on farm with the price ranged from 25,000 IDR to 40,000 IDR per liter. There was no problem in selling of goat milk. Farmers even said that 
Pak. J. Nutr., 14 (3): 141-145, 2015

Table 2: Flock sizes, milk production and milk quality of three dairy goat farms selected as respondents in Payakumbuh West Sumatra

\begin{tabular}{llll}
\hline & - & Farm 2 & Farm 3 \\
\hline Dairy goat population, heads & Farm & & 50 \\
Total population & 54 & 92 & 45 \\
Does & 30 & 33 & 3 \\
Bucks & 3 & 4 & 2 \\
Young does & 0 & 19 & 0 \\
Young bucks & 1 & 12 & 0 \\
Kids & 20 & 24 & 20 \\
\hline Milk production & 8 & 17 & $10-12$ \\
Lactation does, heads & $8-9$ & 13 & 0.5 \\
Total (L/day) & 1 & $1-1.5$ & $6.67 \pm 1.09$ \\
Average (L/doe/day) & & & $1.0291 \pm 0.0001$ \\
Physical characteristics of milk & $5.33 \pm 0.27$ & $6.33 \pm 0.98$ & $6.6 \pm 0.05$ \\
Fat content of milk (\%) & $1.0328 \pm 0.0002$ & $1.0307 \pm 0.0007$ & $1.17 \pm 0.14$ \\
Specific gravity (g/ml) & $6.6 \pm 0.05$ & $6.5 \pm 0.00$ & $8.46 \pm 0.17$ \\
pH & $1.00 \pm 0.00$ & $2.30 \pm 0.54$ & $4.25 \pm 0.50^{\mathrm{a}}$ \\
Catalase number (ml) & & & \\
Microbial milk qualities & $8.13 \pm 0.09$ & $0.04 \pm 0.38$ & \\
TPC, log CFU/ml & $2.20 \pm 0.44^{\mathrm{b}}$ & & \\
Coliforms, log CFU/ml & & & \\
\hline
\end{tabular}

they could not fulfill demand from their costumers which come not only from Payakumbuh but also from Padang, Bukittinggi, Pekanbaru and Medan city. The loyal costumer admitted that goat milk has peculiar properties and healthful. Goat milk is richer than cow milk in some important nutrients: vitamin A, niacin, choline and inositol; but it is poorer in folic acid (Kipserem et al., 2011; Norris et al., 2011). Goat milk also contained a higher proportion of short and medium chain fatty acids with smaller globules than cow milk; this makes goat milk promising in relieving stress and constipation (Gurmesa et al., 2011; Ozung et al., 2011). It has also been found to contain higher medicinal value (curing people with migraine and asthma), vitamin B content and higher digestibility than cow milk (Ochepo and Momoh, 2010). Market demand for this product will grow in the future in accordance with the increasing of the human welfare and public awareness on health.

Conclusion: Dairy goat farm has better prospect in compare to meat-types as an alternative livestock enterprise suitable for small-scale farmer or part-time livestock producer in Payakumbuh region. The potential market for goat's milk and higher price of bucks made the farmer to be able to increase their farm scale and to raise their goats more intensively in order to achieve better production performances and incomes. The result shows that dairy goat enterprises are more profitable than meat-type one.

\section{REFERENCES}

Alexopoulos, A., G. Tzatzimakis, E. Bezirtzoglou, S. Plessas, E. Stavropoulou, E. Sinapis and Z. Abas, 2011. Microbiological quality and related factors of sheep milk produced in farms of NE Greece. Anaerobe, 17: 276-279.
Bacteriological Analytical Manual: Department of Health and Human Services. U.S. Food and Drug Administration, 2004. Staphylococcus enterotoxinproduction in foam and current dairy industry balance tank practices. Department of Health and Human Services.

BSN (Badan Standardisasi Nasional), 2009. Batas Maksimum Cemaran Mikroba dalam Pangan. SNI 7388:2009, Jakarta.

BSN (Badan Standardisasi Nasional), 2011. Susu Segar Bagian 1 Sapi. SNI 3141.1:2011, Jakarta.

Dinas Peternakan Provinsi Sumatera Barat, 2012. Data Base Peternakan Provinsi Sumatera Barat Tahun 2002 s/d 2011. Dinas Peternakan Provinsi Sumatera Barat. Padang.

Dwitania, D.C. and I.B.N. Swacita, 2013. Uji didih, alkohol, dan derajat asam susu sapi kemasan yang dijual di Pasar Tradisional Kota Denpasar. Indonesia Medicus Vet., 2: 437-444.

Faruque, S.A., S.A. Chowdhury, N.U. Siddiquee and M.A. Afroz, 2010. Performance and genetic parameters of economically important traits of Black Bengal goat. J. Bangladesh Agric. Univ., 8: 67-78.

FDA, 2001. U.S. Food and Drug Administration, Methods for Specific Pathogens: Escherichia coli, Salmonella and Vibrio, 8th edition. 2001. FDA Center for Food Safety and Applied Nutrition, Bacteriological Analytical Manual.

Firmansyah, H., R.A.A. Maheswari and B. Bakrie, 2004. Effectiveness of lactoperoxidase system activator in milk preservation of different volume. Seminar Nasional Teknologi Peternakan dan Veteriner.

Gurmesa, U., D. Misgana, H. Feyisa and M. Merga, 2011. Participatory analysis of problems limiting goats production at selected districts of East Showa Zone, Ethiopia. Afr. J. Agric. Res., 6: 5701-5714. 
ISO (International Organization for Standardization), 2003a. ISO 6888-1:1999 A1: 2003. International Standard: Microbiology of food and animal feeding stuffs-Horizontal method for the enumeration of coagulase-positive staphylococci (Staphylococcus aureus and other species). Part 2: Technique using Baird Parker agar medium. The International Organization for Standardization. Geneve.

ISO (International Organization for Standardization), 2003b. ISO 4833:2003. International Standard: Microbiology of food and animal feeding stuffsHorizontal method for the enumeration of microorganism-Colony-count technique at 30 degrees $\mathrm{C}$. The International Organization for Standardization. Geneve.

ISO (International Organization for Standardization), 2003c. ISO 4832:2006. International Standard: Microbiology of food and animal feeding stuffsHorizontal method for the enumeration of coliformscolony-count technique. The International Organization for Standardization. Geneve.

Kipserem, J., T. Sulo, W. Chepng'eno and M. Korrir, 2011. Analysis of factors affecting dairy goat in Keiyo North and Keiyo South District of Kenya. J. Dev. and Agric. Econ., 3: 555-560.

Macha, E. and S.H. Mbaga, 2009. The contribution of small scale dairy farming to households income: $A$ case of Ilala Municipal, Dar es Salaam Region, Tanzania. In: Proceedings of 33rd Annual Scientific Conference, BOT hall, Mwanza, Tanzania, 22-25 September, 2009, pp: 256-275.

Norris, D., J.W. Ngambi, K. Benyi and C.A. Mbajiorgu, 2011. Milk production of three exotic dairy goat genotypes in Limpopo Province, South Africa. Asian J. Anim. and Vet. Adv., 6: 274-281.

Ochepo, G.O. and M. Momoh, 2010. Developing the dairy goat industry in Nigeria. A review. In: Proceedings of the 35th Conference Nigerian Society for Animal Production, 14-17 March, University of Ibadan, Nigeria, pp: 530-532.
Ogola, T.D.O., W.K. Nguyo and I.S. Kosgey, 2010. Dairy goat production practices in Kenya: Implications for a breeding programme. Livestock Research for Rural Development. [http://www.Irrd.org//rrd] site visited on 11/2/2012.

Ozung, P.O., E.E. Nsa, V.N. Ebegbulem and J.A. Ubua, 2011. The potential of small ruminant production in cross river rain forest zone of Nigeria: A Review. Continental J. Anim. and Vet. Res., 3: 33-37.

Sanjeev Kumar, Birendra Kumar, Rajesh Kumar, Suryamani Kumar, Sunil K. Khatkar and S.K. Kanawjia, 2012. A Review: Nutritional Features of Goat Milk. Ind. J. Dairy Sci., 65.

Saragih, C.I., Ketut Suada and I. Putu Sam, 2013. Ketahanan Susu Kuda Sumbawa Ditinjau dari Waktu Reduktase, Angka Katalase, Berat Jenis, dan Uji Kekentalan. Indonesia Medicus Vet., 2: 553-561.

Steel, R.G.D., J.H. Torrie and J.H. Dicky, 1997. Principles and Procedures of Statistics: A Biometritrical Approach. 3rd Ed. McGraw-Hill Book Co. Inc., New York, USA.

Sudarwanto, M. and dan E. Sudarnika, 2008. Hubungan antara $\mathrm{pH}$ Susu dengan Jumlah Sel Somatik Sebagai Parameter Mastitis Subklinik. Media Peternakan, hlm, 107-113.

Suguna, M., Rajeev Bhat and W.A. Wan Nadiah, 2012. Microbiological quality evaluation of goat milk collected from small-scale dairy farms in Penang Island, Malaysia. Int. Food Res. J., 19: 1241-1245.

Suwito, W. and dan Andriani, 2012. Teknologi penanganan susu yang baik dengan mencermati profil mikroba susu sapi di berbagai daerah. J. Penelitian Pascapanen Pertanian, 9: 35-44. 